\title{
Joanna Handlin Smith, The Art of Doing Good: Charity in Late Ming China
}

André Laliberté

\section{(2) OpenEdition}

\section{Journals}

Édition électronique

URL : http://journals.openedition.org/chinaperspectives/5283

DOI : 10.4000/chinaperspectives.5283

ISSN : 1996-4617

Éditeur

Centre d'étude français sur la Chine contemporaine

\section{Édition imprimée}

Date de publication : 1 juin 2010

ISSN : 2070-3449

\section{Référence électronique}

André Laliberté, "Joanna Handlin Smith, The Art of Doing Good: Charity in Late Ming China », China Perspectives [En ligne], 2010/2 | 2010, mis en ligne le 05 août 2010, consulté le 22 septembre 2020. URL : http://journals.openedition.org/chinaperspectives/5283 ; DOI : https://doi.org/10.4000/ chinaperspectives.5283

Ce document a été généré automatiquement le 22 septembre 2020.

(C) All rights reserved 


\title{
Joanna Handlin Smith, The Art of Doing Good: Charity in Late Ming China
}

\author{
André Laliberté
}

Joanna Handlin Smith, The Art of Doing Good: Charity in Late Ming China, Berkeley, University of California Press, 2009, 406 pp.

2 Joanna Handlin Smith is chief editor of the prestigious Harvard Journal of Asiatic Studies. The material she has gathered together in this volume is the fruit of more than two decades of research, and has been published previously in academic journals such as the Journal for Asian Studies and the Journal for the Economic and Social History of the Orient, as well as in the collective work Philanthropy in the World's Traditions. Although the present volume is about a major social phenomenon during the final 50 years of the Ming dynasty, it raises an issue that is very relevant to contemporary Chinese reality. In the current situation in which the state is attempting to ensure social stability by setting up more generous social security provisions and by establishing the means to help socially and economically vulnerable populations, many are inquiring about the role of philanthropy in supporting the state.

This is the first work published in English since 1912 that is devoted entirely to philanthropy in China. The author notes that until the 1980s this research topic was considered insignificant, since studies by Christian missionaries in the nineteenth century had largely discouraged serious research on this issue. Consequently, there has been a longstanding belief that the Chinese only practice charity towards their own relatives, that their benevolence lacks piety and is not entirely disinterested, and that it only serves the interests of the elite. The attacks on Chinese traditions conducted by the Chinese themselves in the twentieth century have simply reinforced this dominant Western view, which is sceptical of the existence of any tradition of philanthropy in China. And yet, as Smith reminds us, the Chinese language has a vast store of terms for charitable activities, suggesting a deeply rooted social practice in that country. 
Jacques Gernet has already described the vitality of the clubs, regular meetings, and literary circles that proliferated in the century before the end of the Ming dynasty in 1644, giving us a glimpse of a many-faceted or even pluralistic China dominated by remarkable intellectual ferment. ${ }^{1}$ Smith's portrayal of the "associations for the common good" (tongshan hui) and other philanthropic associations further enriches our view of that time. She is careful to avoid reliance on criteria taken from Western experience when she tries to identify the principles that motivated Chinese philanthropists in the Ming period. Her study shows great sensitivity over the problem of comparing them with charitable practices in the West, which were intimately connected with religious institutions and were defined as activities taking place outside the family circle. She also notes the absence in China of a clear distinction between the charity practiced by leading figures in the community and the traditional mission of helping the unfortunate, which fell to the state. Since the charitable activities at the end of the Ming era have left few records behind, owing to the destruction brought on by the subsequent political disorder, the author has compensated for this lacuna by her close scrutiny of the writings of five outstanding figures who took the initiative to set up and sustain philanthropic activities in the province of Zhejiang. These five figures lived between 1548 and 1672, during the tumultuous time when the Ming Empire reached its heights and then fell victim to its own internal contradictions before being overrun by the Manchus.

The work is divided into two parts. In the opening section, the author takes five chapters to set out the early development of the charitable associations that these five personalities established, and in the next section she presents four studies of the role they played in a crisis situation. In the first chapter she takes a close look at the associations for the liberation of animals (fangsheng hui), which she considers precursors of the charitable associations because of their espousal of the values of universal compassion, but also because of their concern with the preservation of social order. In the following chapter she discusses the charitable associations and their founders, emphasising the extent to which the authority of the latter depend less on the size of their landholdings or their influential connections than on the strength of their moral convictions. The third chapter shows how these charitable associations, the first of their kind in China, were an alternative not only to the Buddhist institutions and the state, but also to the rural agreements (xiangyue), those institutions through which state functionaries sought to inspire proper behaviour. They were also different from private charity and from the practice of making gifts through clan lineage organisations. In the fourth chapter, Smith shows that the charitable associations emerged in response to a new economic reality, namely the rise of a prosperous merchant class eager to secure its legitimate place in the moral economy of China. These people saw in the practice of philanthropy a way of showing that true worth was not founded solely in the knowledge of the classics, which was in the hands of the literati. The following chapter throws a different light on the charitable associations by focussing on the writings left by Lu Shiyi. Lu was a guiding light behind the founding of a charitable association, but he came from a more humble background than his peers. In Smith's view, his testimony, which offers a realistic and disenchanted description of these associations and the context in which they developed, is especially useful and informative because it highlights the fact that it was the optimism of the leading figures that enabled them to develop their charitable activities with confidence. 
Each of the crises examined by Smith throws a different light on the charitable associations. In Chapter Six she proposes a psychological explanation to help understand the ability of Shaoxing Prefecture's population to mobilise in the face of a famine. This mobilisation seems to have been made possible through the constant pressure brought to bear by the prefect, Qi Biaojia, a rich landowner in the area who headed a charitable association and was said to have been moved to act following the death of his mother. Chapter Seven puts forward a major argument that cannot fail to interest any reader concerned with contemporary problems: official support from the public administration proved to be essential for the effective organisation of aid by the philanthropic associations. In the following chapter Smith emphasises the social interaction initiated by the philanthropic associations. She shows that the supply of medicines and other good works gave individuals from different social backgrounds the chance to assert their influence. Finally, in the last chapter, she shows the extent to which actions by the philanthropists contributed towards transforming social morality in Shaoxing Prefecture in the late Ming dynasty. Her conclusion is that these good works were not so much a matter of moral obligation as they were a source of intense feelings of fulfilment, thanks to the inspiration from some exceptional individuals.

Smith's study of the writings left by the leading figures who established the philanthropic associations have led to some unforeseen conclusions. Those associations acquired exceptional prominence, and left their mark on posterity because of two major social changes: firstly, the expansion of the imperial examinations system, which led to the formation of a social layer of aspirants to administrative rank who could make a career in trade, publishing, or writing if they failed in the examinations; and secondly, an unprecedented social mobility, in which the elite and the popular classes entered into closer relationships. In addition, these writings also show the importance of the local political authorities, even when the authority of the central government seemed to be weakening. Another unexpected fact noted by Smith is that four out of the five philanthropic society leaders whom she studies belonged to the local elite. Fear of social disorder, personal tragedies, and the concern to keep up clan reputation were all factors that pushed them in that direction. It is nonetheless remarkable that these individuals took that course of action because, as Smith observes, anyone who devoted significant energy and material resources to charitable activities ran the risk of fuelling the jealousy of his peers.

This volume raises a great number of relevant questions with regard to China today. To what extent is the desire "to do good" still a possible motive for philanthropy? To what extent do the new generations of entrepreneurs actually wish to give financial support to the development of charities? What role are the religious associations called upon to play in such trends? The importance of this book is that it contributes to a refutation of the negative perceptions and prejudices about a supposed lack of altruism in Chinese society. While it is common to read about the lack of charity, compassion, and disinterested behaviour in Chinese tradition as an explanation for the difficulties encountered in setting up philanthropic associations in China today, Smith's work gives the lie to such a simplistic idea. She shows that there has been a longstanding philanthropic tradition in that country, and that there is therefore a vast reservoir of practices on which contemporary charitable associations can draw. However, this argument should not lead to excessive optimism: a huge chasm separates the China of the Ming dynasty from the People's Republic. Although the development 
of communications, the increase in the general wealth, and the resources of the state may facilitate the establishment and extension of independent philanthropic networks, the demands of contemporary consumerism and the state's distrust of independent organisations constitute considerable obstacles to such a development.

Translated by Jonathan Hall

Glossary

fangsheng hui 放生會

Lu Shiyi 陸世儀 -

Qi Biaojia 祁虎佳

tongshan hui 同善會

xiangyue 鄉約

\section{NOTES}

1. Jacques Gernet, L'intelligence de la Chine: le social et le mental, Paris, Gallimard, 1994, pp. 88-97. 